\title{
A STUDY ON EPIDEMIOLOGY, CAUSES AND PROGNOSIS OF ACUTE RENAL FAILURE IN INDIAN POPULATION
}

\author{
Tejaswi C. N1, Kanavi Roopa Shekharappa², Lakshmikantha B. M³, Smilee Vivian', Vedavathi K. J5 \\ ${ }^{1}$ Assistant Professor, Department of General Medicine, BGS Global Institute of Medical Sciences, Bangalore, Karnataka. \\ ${ }^{2}$ Associate Professor, Department of Physiology, BGS Global Institute of Medical Sciences, Bangalore, Karnataka. \\ ${ }_{3}^{3}$ Associate Professor, Department of Anatomy, DM Wayanad Institute of Medical Sciences, Meppadi Post, Kerala. \\ 4 Professor, Department of Physiology, JJM Medical College, Davangere, Karnataka. \\ 5Professor and HOD, Department of Physiology, BGS Global Institute of Medical Sciences, Bangalore, Karnataka.
}

\section{ABSTRACT}

\section{AIM}

To study the Epidemiology various aetiological, precipitating factors, pattern of complications and the prognosis with reference to immediate outcome of acute renal failure cases.

\section{MATERIALS AND METHODS}

It was a prospective study under which fifty cases of acute renal failure admitted in various units of the Department of Medicine were studied under different parameters like age, sex, clinical presentation, causes, complication and prognosis in BGS Global Institute of Medical Sciences Hospital from 2013 to 2015. The outcome of ARF in each case was documented and percentages were calculated.

\section{RESULTS}

The most common cause of ARF in developing country being acute gastroenteritis $42 \%$ of cases, snake bite $28 \%$ of cases, malaria $6 \%$ of cases, hepatorenal syndrome $4 \%$ cases, obstetrics causes $4 \%$ cases, sepsis $4 \%$ and rest other causes being $2 \%$ each. The commonest complication being electrolyte imbalance among ARF cases. Out of the 50 cases studied, 17 died in the hospital suggesting a mortality of 34\%; 14 patients were referred for dialysis and were lost to follow up (28\%); 18 patients (36\%) had complete recovery from ARF.

\section{CONCLUSION}

The most common cause of ARF is gastroenteritis, so simple remedial measures like using clean sanitary, drinking water, improvement of general hygiene, good obstetric care, control of mosquitoes and use of oral rehydration solution for diarrhoea can go a long way in decreasing the incidence of ARF in the developing world. Physician should be aware of the complication, close attention to haemodynamic, volume status and avoidance of nephrotoxic medications is important to have better outcome in ARF patient.

\section{KEYWORDS}

Acute Kidney Injury, Acute Renal Failure, Cause, Epidemiology, Prognosis.

HOW TO CITE THIS ARTICLE: Tejaswi CN, Shekharappa KR, Lakshmikantha BM, et al. A study on epidemiology, causes and prognosis of acute renal failure in Indian population. J. Evolution Med. Dent. Sci. 2016;5(73):5388-5393, DOI: $10.14260 /$ jemds/2016/1223

\section{INTRODUCTION}

Acute Renal Failure (ARF) often referred to as Acute Kidney Injury (AKI) is characterised by sudden (i.e. hours to days) impairment of kidney function. AKI now understood to be an increasingly common and potentially catastrophic complication in hospitalised patients. 1 There are many Western studies conducted on the causes and prognosis of ARF, but very few Indian studies. So this study was conducted with the aim being to study the Epidemiology, various aetiological, precipitating factors, pattern of complications and the prognosis with reference to immediate outcome of acute renal failure patients.

Financial or Other, Competing Interest: None.

Submission 16-05-2016, Peer Review 08-07-2016,

Acceptance 14-07-2016, Published 12-09-2016.

Corresponding Author:

Dr. Tejaswi C. N,

Assistant Professor,

Department of General Medicine,

BGS Global Institute of Medical Sciences,

Bangalore, Karnataka.

E-mail: tejnat@gmail.com

DOI: 10.14260/jemds/2016/1223

\section{MATERIALS AND METHODS}

The present work is a prospective study conducted in BGS Global Institute of Medical Sciences Hospital from 2013 to 2015. This study consists of fifty cases with symptoms and signs of acute renal failure admitted under various units of the Department of Medicine.

Acute renal failure is defined as a deterioration of renal function over a period of hours to days, which results in an increase in serum creatinine of $>0.5 \mathrm{mg}$ per decilitre over the baseline value, an increase of more than 50 percent over the baseline value or a decrease in renal function that results in the need for dialysis. Oliguria (Urine output of less than 400 $\mathrm{mL} /$ day) is a frequent but not invariable clinical feature. ARF may or may not be symptomatic.

\section{Criteria for Selection of Patients}

1. Patients who satisfied the above clinical criteria were included in the study.

2. Patients with signs and symptoms suggesting acute renal failure due to obstructive uropathy were excluded from the study after abdominal ultrasonography. 
3. Patients who presented with symptoms and signs suggesting prerenal ARF, who improved after correction of haemodynamic status within 24 hours were excluded from the study.

4. Patients with past history of renal disease were excluded from the study.

5. Only inpatients were included in the study.

A detailed history of the age, sex, socioeconomic status, presenting complaints were obtained; the chronological account of the problems, the treatments undergone prior to admission and associated symptoms were obtained. History of any pre-existing renal disease was obtained and patients were investigated for the underlying causes for ARF.

At the same time, patients were started on appropriate conservative therapy. Whenever possible the aetiological factors were treated or the offending agents withdrawn. Restoration of systemic and renal haemodynamic was undertaken with volume repletion when necessary.

The patient was monitored for the development of complications during the stay in the hospital, such as volume overload, oedema, symptoms and signs of uraemia, electrolyte and acid base disturbances, infection and septicaemia, anaemia and bleeding.

Patient was referred for dialysis if the patient had clinical or biochemical deterioration despite conservative therapy or when the patients presented with severe uraemia.

Other organ failure developing during the stay was documented. The outcome of the ARF and the patient in each case was documented and percentage was calculated.

\section{OBSERVATIONS AND RESULTS}

Fifty patients diagnosed to have ARF as per the criteria described previously were studied and the following observations were noted.

\section{Age}

The age of the patients included in the present study ranged from 13 to 82 years.

\begin{tabular}{|c|c|c|}
\hline Age Group & No. of Patients & Percentage \\
\hline 12-25 Years & 11 & $22 \%$ \\
\hline $26-40$ Years & 12 & $24 \%$ \\
\hline $41-55$ Years & 12 & $24 \%$ \\
\hline > 55 Years & 15 & $30 \%$ \\
\hline \multicolumn{2}{|c|}{ Table 1: Showing the Distribution of Age } \\
among ARF Patients \\
\hline
\end{tabular}

\section{Sex}

Out of the 50 cases studied, 35 were males and 15 were females with a male:female ratio of 7:3.

\section{Occupation}

Out of 35 males 25 males were involved in agricultural activity, remaining in non-agricultural activity. Out of the 15 females, 7 were involved in agriculture activity.

\section{Occupational Status}

\begin{tabular}{|c|c|c|}
\hline Sex & Agriculture & Non-Agriculture \\
\hline Male & 25 & 10 \\
\hline Female & 7 & 8 \\
\hline \multicolumn{2}{|c|}{ Table 2: Showing Occupational Status of the Patients } \\
\hline
\end{tabular}

\section{Residence}

Out of 50 patients, 40 came from a rural background.

\section{Socioeconomic Status}

Out of the 50 patients, 42 came from low socioeconomic status group and 8 from middle income group.

\section{Wards where the Patients were Primarily Admitted}

Out of 50 patients 45 patients were admitted under medical wards, 2 cases were referred from Obstetric Department (1 septic abortion, 1 pre-eclamptic toxaemia), 2 cases were referred from Surgery Department (1 diabetes mellitus, gangrene foot and septicaemia, 1 abdominal angina) and 1 case from Orthopaedic Department (Crush injury of leg).

\section{Delay in Presentation}

The time from onset of the symptoms to the presentation to this hospital is documented.

- 17 cases $(34 \%)$ presented within 1 day.

- 18 cases $(36 \%)$ presented within 2 days.

- 11 cases $(22 \%)$ presented within 3 days.

- 4 cases $(8 \%)$ in 4 days.

\section{Chronic Diseases Present in the Patients}

\begin{tabular}{|c|c|}
\hline COPD & 3 \\
\hline Diabetes & 3 \\
\hline Cerebrovascular Disease & 1 \\
\hline Hypertension & 3 \\
\hline IHD & 2 \\
\hline Cirrhosis & 1 \\
\hline Chronic Hepatitis B & 1 \\
\hline \multicolumn{2}{|c|}{$\begin{array}{c}\text { Table 3: Showing the Chronic Diseases Presen } \\
\text { in the ARF Patients }\end{array}$} \\
\hline
\end{tabular}

\section{Blood Pressure}

\begin{tabular}{|c|c|c|c|c|}
\hline $\begin{array}{c}\text { Sys. BP } \\
\text { in mmHg) }\end{array}$ & $\begin{array}{c}<60 \\
\mathrm{mmHg}\end{array}$ & $\begin{array}{c}<80 \\
\mathrm{mmHg}\end{array}$ & $\begin{array}{c}<100 \\
\mathrm{mmHg}\end{array}$ & $\begin{array}{c}>100 \\
\mathrm{mmHg}\end{array}$ \\
\hline $\begin{array}{c}\text { No. of } \\
\text { Patients }\end{array}$ & 8 & 9 & 12 & 23 \\
\hline \multicolumn{6}{|c|}{ Table 4: Showing Systolic BP at Admission } \\
\hline
\end{tabular}

\section{Urine Output}

\begin{tabular}{|c|c|c|}
\hline Anuria & $<400 \mathrm{~mL} / \mathrm{day}$ & $>400 \mathrm{~mL} / \mathrm{day}$ \\
\hline 12 & 38 & 0 \\
\hline $\begin{array}{r}\text { Table 5: Showing the Lowest Urine Output (in 24 hours) } \\
\text { during the Hospital Stay is Given Below }\end{array}$ \\
\hline
\end{tabular}

\section{Urine Analysis}

\begin{tabular}{|c|c|}
\hline$>1.018$ & 13 \\
\hline $1.018-1.015$ & 6 \\
\hline$<1.015$ & 31 \\
\hline \multicolumn{2}{|c|}{ Table 6: Urine Specific Gravity given Below } \\
\hline
\end{tabular}

Urine analysis suggesting prerenal azotaemia was seen in $26 \%$ and suggesting intrinsic renal azotaemia in $62 \%$. Urine analysis was of diagnostic importance in only 1 case, which was diagnosed as glomerulonephritis and showed RBC casts, proteinuria and RBCs.

\section{Blood Urea and Serum Creatinine}

The blood urea values ranged from 56 to $296 \mathrm{mg} \%$ with mean of $71.6 \mathrm{mg} \%$. The serum creatinine values ranged from 2.0 to $19.2 \mathrm{mg} \%$ with mean of $2.8 \mathrm{mg} \%$. 


\section{Electrolytes}

- Hyponatraemia (<135 mmol/L) -----------18 cases.

- Hypernatraemia (>145 mmol/L)-----------2 cases.

- Hypokalaemia (<3.5 mmol/L) ---------- 1 cases.

- Hyperkalaemia (7.5 mmol/L)-------------9 cases.

- Hypocalcaemia (<9 mg\%) -------------- 1 case.

Underlying Aetiology of ARF

\begin{tabular}{|c|c|c|c|}
\hline $\begin{array}{c}\text { Sl. } \\
\text { No. }\end{array}$ & $\begin{array}{c}\text { Cause } \\
\text { for ARF }\end{array}$ & $\begin{array}{c}\text { Number } \\
\text { of Cases }\end{array}$ & Percentage \\
\hline 1 & $\begin{array}{c}\text { Acute } \\
\text { Gastroenteritis }\end{array}$ & 21 cases & $\begin{array}{c}42 \% \text { of the } \\
\text { cases }\end{array}$ \\
\hline 2 & Snake Bite & 14 cases & $\begin{array}{c}28 \% \text { of the } \\
\text { cases }\end{array}$ \\
\hline 3 & Malaria & 3 cases & $6 \%$ of the cases \\
\hline 4 & $\begin{array}{c}\text { Hepatorenal } \\
\text { Syndrome }\end{array}$ & 2 cases & $4 \%$ of the cases \\
\hline 5 & $\begin{array}{c}\text { Obstetric Causes } \\
\text { 1 Septic Abortion } \\
\text { Toxaemia) }\end{array}$ & 2 cases & $4 \%$ of the cases \\
\hline 6 & Sepsis & 2 cases & $4 \%$ of the cases \\
\hline 7 & Crush Syndrome & 1 cases & $2 \%$ of the cases \\
\hline 8 & $\begin{array}{c}\text { Cardiogenic Shock } \\
\text { due to MI }\end{array}$ & 1 cases & $2 \%$ of the cases \\
\hline 9 & $\begin{array}{c}\text { Abdominal Angina } \\
\text { known IHD }\end{array}$ & 1 cases & $2 \%$ of the cases \\
\hline 10 & Glomerulonephritis & 1 cases & $2 \%$ of the cases \\
\hline 11 & $\begin{array}{c}\text { Gangrene Leg } \\
\text { Diabetes Mellitus }\end{array}$ & 1 cases & $2 \%$ of the cases \\
\hline 12 & $\begin{array}{c}\text { Malignant } \\
\text { Hypertension }\end{array}$ & 1 cases & $2 \%$ of the cases \\
\hline \multicolumn{2}{|c|}{$\begin{array}{c}\text { Table 7: Shows the Causes in Descending } \\
\text { Order of Frequency }\end{array}$} \\
\hline
\end{tabular}

Duration of Stay in the Hospital: The mean duration of many in the hospital was 4 days. The maximum duration of stay was 26 days and the minimum was 1 day.

\section{Complication of ARF}

\begin{tabular}{|c|c|}
\hline Complications & No. of Cases \\
\hline Volume Overload & 16 \\
\hline Anaemia & 10 \\
\hline Bleeding & 1 \\
\hline Infection & 13 \\
\hline Electrolyte Disturbances & 31 \\
\hline Uraemia & 14 \\
\hline \multicolumn{2}{|c|}{$\begin{array}{c}\text { Table 8: Showing the Complication of ARF Developed in } \\
\text { the Patients included in the Study }\end{array}$} \\
\hline
\end{tabular}

Dialysis: The number of patients referred for dialysis because of clinical deterioration or development of complication was $14(28 \%)$.
Other Organ Failure Developing During Admission Were

\begin{tabular}{|c|c|}
\hline Organs Involved & No. of Cases \\
\hline Respiratory Failure & 5 \\
\hline Heart Failure & 3 \\
\hline Liver Failure & 2 \\
\hline Septicaemia & 7 \\
\hline Table 9: Showing Organ Failure Developed in ARF \\
Patients during Admission
\end{tabular}

\section{Outcome}

Out of the 50 cases studied, 17 died in the hospital suggesting a mortality of 34 percent; 14 patients were referred for dialysis and were lost to follow up (28\%); 18 patients (36\%) had complete recovery from ARF. Out of 21 gastroenteritis cases, 13 had complete recovery in hospital; 5 were referred for dialysis and 3 died in the hospital. Out of 14 snake bite patients 5 patients had complete recovery, 4 patients died and 5 patients were referred for dialysis and lost for followup.

\begin{tabular}{|c|c|c|}
\hline Complete Recovery & 18 Cases & $36 \%$ \\
\hline Referred for dialysis & 14 cases & $28 \%$ \\
\hline Mortality & 17 cases & $34 \%$ \\
\hline
\end{tabular}

\section{DISCUSSION}

The aetiology, course and outcome of ARF are closely linked to the prevailing socioeconomic and environmental conditions in a given geographic location. Consequently, a large disparity exists between the aetiology of acute renal failure in the economically advanced countries with temperate climates and that in the third world countries with limited resources and exposure to tropical conditions.

The true incidence of ARF in the community is available only from limited geographical zones. A survey of 32 centres engaged primarily in chronic dialysis in Europe, North Africa and Middle East revealed that 29 patients/million/year required acute dialysis. Comparable data however are not available from most tropical countries. If referrals to the dialysis units are a reliable guide, the condition is far more frequent in Asia (Chugh et al 1991). ${ }^{2}$ The question regarding the incidence of milder forms of ARF has been addressed by only three studies (Hou et $\mathrm{al}^{3}$ 1983, M.J. Hanley et $\mathrm{al}^{4}$ 1981, Kumar et al ${ }^{5}$ 1973), whereas $2-4 \%$ of all hospital admissions had ARF of varying severity, only $8-14 \%$ of these required dialytic support.

\section{Patterns of ARF}

The contribution of medical, surgical and obstetrical conditions to the overall pattern of ARF in the tropics is distinctly different from that observed in the West.

\begin{tabular}{|c|c|c|c|c|c|c|}
\hline Country & Authors & Year & No. of Pts & Med \% & Obst \% & Surgical \% \\
\hline USA & Hall et al 6 & 1970 & 186 & 35 & 8 & 57 \\
\hline France & Klienknecht et al7 & 1972 & 500 & 26 & 28 & 46 \\
\hline U.K. & Kennedy et al ${ }^{8}$ & 1973 & 251 & 22 & 25 & 53 \\
\hline U.K. & Kerr et al ${ }^{9}$ & 1974 & 503 & 40 & 11 & 49 \\
\hline Australia & Rasmussen et al ${ }^{10}$ & 1985 & 148 & 43 & 0 & 57 \\
\hline Canada & Lein et al 11 & 1985 & 58 & 50 & 0 & 50 \\
\hline USA & Abrea et al ${ }^{12}$ & 1985 & 46 & 41 & 2 & 57 \\
\hline U.K. & Beaman et al ${ }^{13}$ & 1987 & 250 & 50 & 3 & 47 \\
\hline USA & Corwin et al14 & 1987 & 51 & 50 & 0 & 50 \\
\hline USA & Shusterman et al ${ }^{15}$ & 1987 & 34 & 53 & 3 & 44 \\
\hline U.K. & Wheeler et al ${ }^{16}$ & 1988 & 408 & 60 & 2 & 33 \\
\hline
\end{tabular}


Analysis of ARF in the West prior to 1980 revealed that 8 $28 \%$ of cases were due to obstetric complications, while $22-$ $40 \%$ and $46-57 \%$ were due to medical and surgical conditions respectively. (Hall 1970,6 Kleinknecht 1972,7 Kennedy $1973^{8}$ and Kerr 19749). During the same period, 15-29\% of ARF in the tropical countries was due to obstetric events, while the contributions of medical and surgical ARF were $58-67 \%$ and 4-24\% respectively. (Ku 1975,17 Firmat 1975,18 Sitprija $1975,{ }^{19}$ Adu $1976,{ }^{20}$ Chugh $1978^{21}$ and Scedat $1978^{22}$ ). Thus, in the previous two decades the main disparity in the pattern of ARF between the developed and developing countries was the preponderance of surgical ARF in the West and medical ARF in the tropics. The incidence of Obstetric ARF was not appreciably dissimilar.

Rapid advances in medical care in the industrialised nations have led to the virtual eradication of obstetric ARF which now constitutes less than $3 \%$ in all cases of ARF. Although, the relative contribution of medical and surgical ARF has not changed appreciably, there has been a steady increase in the mean age of patients with ARF and a tendency for patients with severe illnesses to survive long enough to develop ARF. (Rasmussen 1985,10 Lein 1985,11 Beaman 1987,13 Corwin 1987,14 Schusterman 198715 and Wheeler $\left.1988^{16}\right)$. Thus despite advances in dialysis and critical care, the mortality of ARF continues to be in the range of $36-72 \%$ with patients dying not from ARF, but with ARF (Hall J $1970^{6}$ and Eliahou 196423).

In the tropics too changes have occurred in the pattern of ARF, albeit at a less impressive pace when compared to the West (Chugh K.S. 1978,21 Rashid $1988^{24}$ and Perriera 198825). In North India, Obstetric ARF is declined from $21-22 \%$ in the past to $9 \%$ in recent years. During the same period, surgical ARF has increased from $11 \%$ in the 1960 s to $24 \%$ in the 1970 s and $30 \%$ in the $1980 \mathrm{~s}$. The contribution of acute renal failure from medical causes has remained between $55-67 \%$ of all cases of ARF, whereas sepsis, nephrotoxic drugs, open heart surgery in poor risk patients, cardiogenic shock and severe trauma following industrial and traffic accidents have emerged as the leading cause of ARF in developed countries (Rasmussen 1985,10 Lein 1985,11 Beaman $1985^{13}$ and Schusterman 198715). The tropical hospitals continue to be inundated by patients with ARF due to diarrhoeal disease, obstetric to be inundated by patients with ARF due to diarrhoeal disease, obstetric complications and environmental agents specific to this region (Shah 1985,26 Muthusethupathi 198727 and Perriera 198825).

In this study only patients admitted under medical wards were taken up for analysis; 50 cases were studied. The incidence of ARF due to medical causes in this study is given below in descending order of frequency.

$\begin{array}{lll}\text { Diarrhoeal disease (21 cases) } & - & 42 \% \\ \text { Snake bite (14 cases) } & - & 28 \% \\ \text { Malaria (3 Cases) } & - & 6 \% \\ \text { Sepsis (2 Cases) } & - & 4 \% \\ \text { Hepatorenal syndrome (2 cases) } & - & 4 \% \\ \text { Glomerulonephritis (1 case) } & - & 2 \% \\ \text { Obstetric cases (2 cases) } & - & 4 \% \\ \text { Miscellaneous (5 cases) } & - & 10 \%\end{array}$

The mortality rate in our study was $34 \%$ (17 cases). These data are compared with other studies.

\begin{tabular}{|c|c|c|c|c|c|c|}
\hline Country & Authors & Year & No. of Pts & Med \% & Obst \% & Surg \% \\
\hline Singapore & Ku et al ${ }^{17}$ & 1975 & 143 & 60 & 16 & 24 \\
\hline Indonesia & Oesman et al ${ }^{28}$ & 1975 & 48 & 63 & 29 & 8 \\
\hline Argentina & Firmat et al $^{18}$ & 1975 & 1000 & 58 & 28 & 14 \\
\hline Thailand & Sitprija et al19 & 1975 & 162 & 61 & 15 & 24 \\
\hline Ghana & Adu et $\mathrm{al}^{20}$ & 1976 & 50 & 62 & 24 & 4 \\
\hline India & Chugh et al21 & 1978 & 325 & 67 & 22 & 10 \\
\hline S. Africa & Seedat et $\mathrm{al}^{22}$ & 1978 & 150 & 65 & 25 & 10 \\
\hline India & Shah et al26 & 1985 & 816 & 56 & 23 & 21 \\
\hline India & Muhusethupathi27 & 1987 & 187 & 85 & 9 & 6 \\
\hline India & Chugh et al 29 & 1987 & 1862 & 60 & 15 & 25 \\
\hline Bangladesh & Rashid et al ${ }^{24}$ & 1988 & 70 & 75 & 9 & 16 \\
\hline
\end{tabular}

1. Chugh K.S. et al from PGIMER Chandigarh.

\begin{tabular}{|c|c|c|c|}
\hline Causes & $\begin{array}{c}\text { Period A } \\
\text { 1965-74 }\end{array}$ & $\begin{array}{c}\text { Period B } \\
\mathbf{1 9 7 8 - 8 0}\end{array}$ & $\begin{array}{c}\text { Period C } \\
\mathbf{1 9 8 1}-\mathbf{8 6}\end{array}$ \\
\hline $\begin{array}{c}\text { Diarrhoeal } \\
\text { Diseases }\end{array}$ & $23 \%$ & $12 \%$ & $10 \%$ \\
\hline $\begin{array}{c}\text { G-6-P D } \\
\text { Deficiency } \\
\text { (IV Haemolysis) }\end{array}$ & $12 \%$ & $12 \%$ & $6 \%$ \\
\hline Snake Bite & $3 \%$ & $3 \%$ & $2 \%$ \\
\hline $\begin{array}{c}\text { Copper Sulphate } \\
\text { Poisoning }\end{array}$ & $5 \%$ & $2 \%$ & $1 \%$ \\
\hline $\begin{array}{c}\text { Glomerulonephr } \\
\text { itis }\end{array}$ & $11 \%$ & $9 \%$ & $10 \%$ \\
\hline $\begin{array}{c}\text { Drugs and } \\
\text { Toxins }\end{array}$ & $4 \%$ & $5 \%$ & $7 \%$ \\
\hline
\end{tabular}

\begin{tabular}{|c|c|c|c|}
\hline Sepsis & $2 \%$ & $1 \%$ & $8 \%$ \\
\hline Miscellaneous & $7 \%$ & $8 \%$ & $13 \%$ \\
\hline $\begin{array}{c}\text { Percentage of } \\
\text { Total ARF }\end{array}$ & $67 \%$ & $55 \%$ & $61 \%$ \\
\hline Medical Causes & 218 & 283 & 623 \\
\hline All patients & 325 & 510 & 1027 \\
\hline Table 13: Showing the Medical Causes of Acute Renal \\
Failure - Chandigarh Study30 \\
\hline
\end{tabular}

The mortality rates in this series was $41.8 \%$. One important fact about the series was that only dialysed patients with ARF were included in the study.

2. In another study of 187 patients with ARF conducted by Muthusethupathi et al in 1987 from Govt. Royapettah 
Hospital, Madras, the following were the aetiological causes. ${ }^{28}$

\begin{tabular}{|l|c|c|}
\hline Gastroenteritis (44 Cases) & - & $26 \%$ \\
\hline Leptospirosis (10 Cases) & - & $4.8 \%$ \\
\hline Snake Bite (6 Cases) & - & $2.8 \%$ \\
\hline Glomerulonephritis (49 Cases) & - & $26 \%$ \\
\hline Copper Sulphate (21 Cases) & - & $4.8 \%$ \\
\hline $\begin{array}{l}\text { Hepatorenal Syndrome } \\
\text { (2 Cases) }\end{array}$ & - & $11 \%$ \\
\hline G-6-PD Deficiency (1 Cases) & - & $1 \%$ \\
\hline Drug Induced (10 Cases) & - & $0.5 \%$ \\
\hline Sepsis (5 Cases) & - & $5.3 \%$ \\
\hline Obstetric (17 Cases) & - & $9 \%$ \\
\hline Miscellaneous (19 Cases) & - & $10 \%$ \\
\hline \multicolumn{2}{|c|}{ Total 187 Cases } \\
\hline
\end{tabular}

In this study, management of ARF was by conservative methods. It was found that, about one-third of patients with ARF can be managed by conservative measures alone. For nearly three fourths $(71.6 \%)$, dialysis was required. The overall mortality in this series was $27.8 \%$.

It was observed that other common tropical conditions like glomerulonephritis, leptospirosis and copper sulphate poisoning are important causes of ARF in Tamil Nadu.

It was also observed that G-6-PD deficiency causing intravascular haemolysis and ARF was rare in South India (1 case) as compared to Northwest of India (Chandigarh study), ${ }^{30}$ where there was a higher incidence ( $12 \%$ of cases).

Another observation is that leptospiral ARF is common in South India and rare in North India. This has been substantiated by another study by Kasivishweshwaran et al from Kerala. ${ }^{29}$ Other studies from Singapore and Thailand (Sitprija et al $1975^{19}$ and $\mathrm{Ku}$ et al $1975^{17}$ ) has found that leptospirosis is responsible for over $50 \%$ of patients with ARF in these countries. The incidence of pregnancy related ARF was almost similar in the 2 studies of Muthusethupathi 27 and Chugh. 30

\section{Comparison of our Study with these 2 Studies has shown} that

1. Diarrhoeal diseases, snake bites and malaria were the most important aetiological causes of ARF in our study.

2. Cases of suicidal copper sulphate poisoning, leptospirosis and glucose 6-phosphate dehydrogenase deficiency with intravascular haemolysis were not found in our study.

3. Obstetric case of ARF was $4 \%$ in our study compared to 9\% of cases in Muthusethupathi's ${ }^{27}$ study and $9-22 \%$ in the Chandigarh study by Chugh. ${ }^{30}$

4. Drug-induced ARF was not seen in our study as compared to $5.3 \%$ in the Muthusethupathi study ${ }^{28}$ and $4-7 \%$ in the Chandigarh study. 30

This can be explained because only patients with severe acute renal failure were included in our study. In nephrotoxic ARF due to drugs there is preservation of urine flow, so called non-oliguric ARF and it usually manifests as asymptomatic rises in blood urea and serum creatinine and also imparts a lower mortality. But despite widespread use of nephrotoxic medications (ACE inhibitors, NSAIDs), the cause of ARF attributed to these was not statistically significant in the Indian studies as compared to Western studies.

5. There was a rarity of surgical causes (Other than obstructive uropathy) of ARF in our study. This is also conspicuous in the study of Chugh et al ${ }^{29}$ from Chandigarh and Muthusethupathi et al 27 from Madras. The probable reasons are: (1) Lack of awareness of postoperative nonoliguric renal failure on the part of surgical staff, (2) Unwillingness to take up seriously ill patients for surgery, (3) Most cases of mild post-operative renal failure are mixed because of failure to do routine investigations.

6. Conservative therapy was helpful in $38 \%$ of our cases, similar to that of study by Muthusethupathi et al, ${ }^{27}$ where $33 \%$ of patients recovered by conservative measures alone.

7. The mortality of $34 \%$ in our study cannot be compared with that of other studies (Muthusethupathi 27.8\% ${ }^{27}$ and Chugh et al $4.8 \%{ }^{30}$ ), because $28 \%$ of our patients were referred for dialysis and were lost for followup.

\section{Summarising, the Important Facts to be Noted about ARF} in our Country are

1. There was a significant delay in presentation to the hospital, which can be avoided by education of the general public. Delay in presentation affected outcome.

2. The poor socioeconomic conditions, malnutrition, lack of clean, sanitary, drinking water supply and inadequate medical facilities are some of the myriad factors responsible for the wide prevalence of diarrhoeal diseases in third world countries. Preventive measures should entail general improvement in the standard of living and early presentation to the hospital.

3. Snake bite is an occupational hazard in the rural areas of the tropics. The most common species causing acute renal failure are Russell's viper and saw scaled viper (Echinus carinatus). Patients present with a classical history of local swelling, bleeding diathesis and ARF. Timely administration of antivenin in adequate amounts and prompt replacement of blood and fluid losses could conceivably prevent or alternate ARF.

4. Infections are common precipitants of ARF in the tropics. Examples include malaria and leptospirosis. Control of mosquitoes and avoidance of urine and tissues from infected animals, rodent control and avoidance of recreational activities in contaminated water are preventive measures.

5. Obstetric ARF has high incidence in developing countries. The reasons for the continued high incidence are inadequate antenatal, intranatal and postnatal care, prevalence of unsafe home delivery practices and clandestine abortions conducted by untrained personnel. The abortion practices include use of a stick, insertion of abortifacient chemicals and pastes, soap solutions and dilatation and curettage caused under unhygienic conditions.

There has been a decline in the incidence of obstetric ARF over the last care, legalisation of abortion (in 1972), improvement in operative techniques, availability of potent antibiotics and decline in use of the traditional midwife (Dai) for deliveries. 


\section{CONCLUSION}

ARF is a condition in which despite rational supportive and replacement therapy, the mortality rate is still high (Approx. $50 \%)$.

The pattern of ARF in the third world countries is different from that in the developed countries. The common conditions causing ARF in tropics include acute gastroenteritis, infectious diseases, snake bite and pregnancy related causes.

Simple remedial measures like using clean sanitary, drinking water, improvement of general hygiene, good obstetric care, control of mosquitoes and use of oral rehydration solution for diarrhoea can go a long way in decreasing the incidence of ARF in the developing world.

Delay in seeking treatment is an important factor in precipitating ARF and also was associated with adverse outcomes.

On the part of the physician, close attention to haemodynamic and volume status and avoidance of nephrotoxic medications is important.

\section{REFERENCES}

1. Waikar SS, Liu KD, Chertow GM. Incidence and prognostic significance of acute kidney injury. Curr Opin Nephrol Hypertens 2007;16(3):227-36.

2. Chugh KS, Sakhuja V, Pereira BJG. Acute renal failure in the tropics. In: Solez K, Racusen LC, eds. Acute renal failure: diagnosis, treatement and prevention. New York: Marul Dekker 1991:93-103.

3. Hou SH, Bushinsky DA, Wish JB, et al. Hospital acquired renal insufficiency: a prospective study. Am J Med 1983;74(2):243-8.

4. Hanley MJ, Davidson K. Prior mannitol and furosemide infusion in a model of ischemic acute renal failure. Am J Physiol 1981;241(5):F556-64.

5. Kumar R, Hill CM, McGeown MG. Acute renal failure in the elderly. Lancet 1973;1(7794):90-1.

6. Hall JW, Johnson WJ, Maher FT, et al. Immediate and long term prognosis in acute renal failure. Ann Intern Med 1970;73(4):515-21.

7. Kleinknecht D, Jungers P, Chanard I, et al. Uremic and nonureamic complications of acute renal failure: evaluation of early and frequent dialysis on prognosis. Kid Int 1972;1:190-6.

8. Kennedy AC, Burton JA, Luke RG, et al. Factors affecting the prognosis in acute renal failure. Quart J Med 1973;42(165):73-86.

9. Kerr DNS, Elliot RW. The pathogenesis of acute renal failure. In: Flynn CT, ed. Acute renal failure. Lancaster: Medical and Technical Publishing Company 1974:9-36.

10. Rasmussen HH, Pitt EA, Ibels LS, et al. Prediction of outcome in acute renal failure by discriminant analysis of clinical variables. Arch Intern Med 1985;145(11):2015-8.

11. Lein J, Chan V. Risk factors influencing survival in acute renal failure treated by haemodialysis. Arch Intern Med 1985;145(11):2067-9.

12. Abreo K, Moorthy AV, Osborne M, et al. Changing patterns and outcome of acute renal failure requiring hemodialysis. Arch Intern Med 1986;146(7):1338-41.
13. Beaman M, Turney JH, Rodger RSC, et al. Changing patterns of acute renal failure. Quart J Med 1987;62(1):15-23.

14. Corwin HL, Teplick RS, Schreiber MJ, et al. Prediction of outcome in acute renal failure. Am J Nephrol 1987;7(1):812.

15. Schusterman N, Strom BL, Murray TG, et al. Risk factors and outcome of hospital acquired renal failure-clinical epidemiologic study. Am J Med 1987;83(1):65-71.

16. Wheeler DC, Feehally J, Walls J. High risk acute renal failure. Q J Med 1986;61(234):977-84.

17. $\mathrm{Ku} \mathrm{G}$, Lim $\mathrm{CH}$, Pwee HS, et al. Review of acute renal failure in Singapore. Ann Acad Med Singapore 1975;4(Suppl):115-20.

18. Firmat J, Pas R. 1000 patients with acute renal failure clinical and pathological observations. In: Giovannetti S, Bonomini V, D'Amico G, (eds). Sixth international congress of nephrology: advances in nephrology physiology, hypertension, renal diseases, renal failure, dialysis, and transplantation: proceedings of the. $6^{\text {th }}$ international congress of nephrology, florence 1975. New York, Basel, Karger S, c1976, abst no 600.

19. Sitprija V, Chslip SR. Renal failure and hyperbilirubinemia in leptospirosis. Treatment with exchange transfusion. Med J Anat 1973;1:171.

20. Adu D, Anim-Addo Y, Foli AK, et al. Acute renal failure in tropical Africa. Br Med J 1976;1(6014):890-2.

21. Chugh KS, Singhal PC, Nath IV, et al. Spectrum of acute renal failures in north India. Journal of Association of Physicians of India 1978;26(3):147-54.

22. Seedat $Y K$, Nathoo BC. Acute renal failure in blacks and indians in South Africa-comparison after 10 years. Nephron 1993;64(2):198-201.

23. Eliahou HE. Mannitol therapy in oliguria of acute onset. Brit med J 1964;1(5356):807-9.

24. Rashid HV, Rahman H, Choudhury D, et al. Acute renal failure in Bangladesh. In: Abstracts article international symposium on prevention, treatment, and diagnosis of acute renal failure: from the laboratory to the clinic. Renal Failure 1989;11(1):43-76. Available from http://dx.doi.org/10.3109/08860228909066946.

25. Pereira S, Pereira BJG, Bhakoo ON, et al. Peritoneal dialysis in neonates with acute renal failure. Indian J Pediatr 1988;55(6):973-8.

26. Shah PP, Trivedi HL, Sharma RK, et al. Acute renal failure experience of 816 patients in tropics (abstract). Fifteenth annual congress of the Indian society of nephrology Bangalore 1985:17.

27. Muthusethpathi MA, Shivakumar S. Acute renal failure in south India. JAPI 1987;35(7):504-7.

28. Oesman R, Markum MS, Rahardjo J, et al. Acute renal failure in general hospital Jakarta. Ann Acad Med (Singapore) Suppl 1975;4:121-3.

29. Chugh KS, Narang A, Kumar L, et al. Acute renal failure amongst children in a tropical environment. Int J Artif Organs 1987;10(2):97-101.

30. Viswesvarn KR. Acute renal failure due to leptospirosis. In: Chugh KS, ed. Asian nephrology. New Delhi: Oxford University Press 1994:384-92. 